\title{
MENTAL HEALTH CONSEQUENCES OF TERRORISM EXPOSURES AMONG YOUTH IN PAKISTANI SOCIETY
}

\author{
Sadia Rafi ${ }^{*}$ \\ Mumtaz $\mathrm{Ali}^{* *}$ \\ Irfan Nawaz ${ }^{* * *}$
}

\begin{abstract}
This study examines the mental health consequences of terrorism exposures among youth in Pakistani society. Using Taaro Yamni formula to draw the sample, research approached 399 youth aged 15-24 years. As a research tool, Impact of Event Scale (IES$R)$ was used with slight modifications. Using Statistical Package of Social Sciences (SPSS) v. 2land Stata v. 20, a multinomial model was applied to explore the relation between different variables. The major findings of the study are that a person who has personal exposure to terrorist attack is the worst affected and the person who was informed by someone is least affected to constant threat to terrorism. Thus, it is suggested that terrorism is threatening mental health of youth therefore counter terrorism policies should be extended to social dimensions. Moreover, severe impacts should be taken into consideration and devise a mechanism to provide counseling services to the victims free of cost. it is imperative to explore the impacts of terrorism on other groups of society including children, and women etc.
\end{abstract}

Keywords: Youth welfare, mental health, terrorism, psychology

\section{Introduction}

With the advent of $21^{\text {st }}$ century came new trials and adversity laden challenges for the denizens of this World. Perhaps one of the most grave and afflicting of said predicaments was none other than the curse of Terrorism. In 2001, terrorists attacked on World Trade Center, USA. In response of these terrorist attacks, USA invaded Iraq and Afghanistan in the name of War against terror. Invading Afghanistan, Pakistan had played a role as a front line state. As a result, a chaotic situation came forth in Pakistan that has serious effects on social, religious, political and psychological spheres of life. Above all, mental health of the inhabitants is at high risk in Pakistani society as some scholars refer 9/11 incident a psychological warfare. ${ }^{1}$

Being neighbor of the war-torn country and as a direct affectee, Pakistan has been suffering from terrorism for many years. In this way, Terrorism has become a constant

* Sadia Rafi, Ph.D. Assistant Professor/Head of Department, , Department of Social Work, University of Sargodha

** Mumtaz Ali, Ph.D. Assistant Professor, Department of Social Work, University of Sargodha

*** Irfan Nawaz, Research Scholar, Department of Social Work, University of Sargodha

${ }^{1}$ Ali, Saleem. Islam and education: conflict and conformity in Pakistan and beyond, (under review by Oxford University Press, 2007) 
threat for the people of Pakistan. Unfortunately, all the way through its history, the citizens of Pakistan have been facing terrorism in various socio-political and military aspects; sectarian, ethnic, and political conflicts. But for the past years, more than 80,000 people have been killed in terrorism. These facts showed the grievance of the menace. ${ }^{2}$

However, Terrorism is multifaceted warfare and the most severe aspect is psychological damages occurred because of it. The mechanism of terrorism may be the blasts, suicide attacks, bio-terrorism, and financial terrorism. ${ }^{3}$ A definition that covers the key elements was cited in the UN Security Council Resolution "Criminal acts, including against civilians, committed with the intent to cause death or serious bodily injury, or taking of hostages, with the purpose to provoke a state of terror in the general public or in a group of persons or particular persons, intimidate a population or compel a government or an international organization to do or to abstain from doing any act. ${ }^{4 "}$ On the other hand, mental health refers to cognitive or emotional well-being. The World health Organization terms mental health as "a state of well-being in which the individual realizes his or her own abilities, can cope with the normal stresses of life, can work productively and fruitfully, and is able to make a contribution to his or her community." ${ }^{5}$

Moreover, a terrorism-affected person may respond in various ways; some may face trauma and in future this trauma may lead toward constant stress and fear. Coping these severe psychological impacts, a person adopts various strategies which may prove helpful. $^{6}$

Keeping in mind, terrorism is not only a problem for the people living in a war zone. Due to globalization, apart from war zones, youth has been facing physical and psychological violence at large because of threat of possible terrorist attacks.

In this way, the often occurrence of attacks, at markets, hotels, religious ceremonies and other public venues, has increased the risk for common people specifically youth to enjoy a healthy life.

Therefore, it has now become the need of the hour to take into consideration the health of the people experiencing terrorism physically or psychologically. Among them, it is vital to address problems facing youth vis-à-vis terrorism in Pakistan. Because, youth is the future of any nation and this youth is more than half of the total population of Pakistan also.

${ }^{2}$ Web desk, "80,000 Pakistanis killed in US 'War on Terror': report," The Tribune, March 29, 2015, accessed on June 06, 2015, http://tribune.com.pk/story/860790/80000-pakistanis-killed-in-us-war-on-terror-report/

${ }^{3}$ Crenshaw, M. "The logic of terrorism: terrorist behavior as a product of strategic choice. In Origins of Terrorism" (Cambridge: Cambridge University press, 1990) Dis 1992; 180: 505-9.

${ }^{4}$ United Nations "Measures to eliminate international terrorism," of December 9, 1994, UN Doc. A/Res./60/49. 1994.Retrieved from http://www.un.org/documents/ga/res/49/a49r060.htm, retrieved on May, 02, 2016

${ }^{5}$ World Health Organization. "Promoting Mental Health: Concepts, Emerging evidence, substance Abuse in collaboration with the Victorian Health Promotion Foundation and the University of Melbourne. World Health Organization. "Geneva 19. J.K.Trivedi. Indian Journal of Psychiatry, (2004), 46 (1) 7-14.

${ }^{6}$ Greenberg,J.,Simon,L., Pyszczynski,T., Solomon,S. \& Chatel,D. Terror management and tolerance: does mortality salience always intensify negative reactions to others who threaten one's world view? Journal of Personality and Social Psychology, (1992). 63,212-220. 


\section{Literature Review}

There are many studies, about impacts of terrorism on youth, conducted in various regions. But a few studies have been carried out in Pakistan on youth in context of terrorism exposures. At international level, mostly researches on terrorism focused on post-traumatic stress disorder among those who were present at the attacks. In addition, a few studies investigated the effects of constant fear among those who were not present at the place of attacks. ${ }^{7}$ Nevertheless, a few studies investigated the effects of constant fear among those who were not present at the place of attacks and some studies exposed indirect exposure like viewing terrorist attacks coverage on television and sort out its effects on mental health. ${ }^{8}$

Saurez assessed the resilience and post-traumatic responses of women native to Quechua in aftermath of political violence in Peru from 1980-2000. For data analysis, hierarchical regression analysis was applied. The findings unveiled that resilience does not contribute to the overall variance of symptoms concerning post-traumatic stress. ${ }^{9}$

Badri et al. explored the association of war exposures and evaluated the post-traumatic stress disorder symptoms among female students belonging to Darfur. For empirical investigation, mean and standard deviations were represented the severity of exposures of war dimensions and post-traumatic symptoms sub-scales. Along with, it was concluded that there is a strong relationship between the war-related trauma exposures and the posttraumatic symptoms. ${ }^{10}$

Naz analyzed the causes and consequences of terrorism in Swat valley. For conducting this study, 180 respondents were interviewed using structured interview schedule. The findings of the study show highly significant relationship between socio-economic factors and consequences of terrorism. Besides, study found that there is a significant relationship between psychological impacts and terrorism. ${ }^{11}$

Qadri and Qadri attempted to highlight the consequential analysis of terrorism and efforts to ensure social justice and equity. Moreover, terrorism was also creating social injustice and negated the equity that threatened the social fabric of Pakistani society. Therefore, it was suggested that for bringing peace and restore harmony it is necessary to beat the

\footnotetext{
${ }^{7}$ Shaley AY. "Posttraumatic stress disorder among injured survivors of a terrorist attack: predictive value of early intrusion and avoidance symptoms." Journal of Nervous and Mental diseases, (Aug, 1992);180(8):505-9

${ }^{8}$ Schlenger WE, Caddle JM, Ebert L, Jordan BK, Rourke KM, Wilson D. "Psychological reactions to terrorist attacks: findings from the National Study of American's Reactions to September 11." JAMA (2002); 288: 581-8.

${ }^{9}$ Suarez, Eliana, "The association between post-traumatic stress-related symptoms, resilience, current stress and past exposure to violence: a cross sectional study of the survival of Quechua women in the aftermath of the Peruvian armed conflict." Conflict and Health, (2013), 7:21, Accessed on December 23, 2015, DOI: 10.1186/1752-1505-7-21

${ }^{10}$ Badri ., Crutzen, Rik, Crutzen and Borne, H W Van den, "Exposures to war-related traumatic events and post-traumatic stress disorder symptoms among displaced Darfuri female university students: an exploratory study."BMC Public Health. (2012); 12: 603. Accessed November 01, 2015, doi: 10.1186/1471-2458-12-603

${ }^{11}$ Naz, Arab., Daraz, umar., Khan, Waseem., Khan Qaisar., \& Khan, Tariq. "Sociological analysis of Terrorism in Pakistan." Academic research journal, (2012),
} 
extremist behavior prevalent in societies by making efforts of international powers united based on unanimous principle of bringing peace. ${ }^{12}$

Ahmad et al. investigated the stress level regarding constant threat of terrorism and coping strategies among university students. A self-structured questionnaire was used to collect data from undergraduate students of four universities of Karachi. The findings of the study are that majority of university students had mild stress level and possible reason for this stress is uncertainty and violence in the environment of Karachi. ${ }^{13}$

In Pakistan, researches about effects of terrorism on students carried out are very few in numbers; even though this portion of population is the future of the nation, therefore it is essential to initiate studies which bring into light terrorism related problems in general. Such studies may help to sort out the existence and intensity of psychological disorders like stress and probe suitable strategies to end this menace. Alarmingly, a significant rise in terrorist attacks has now become a grave threat to youths' sense of safety. This constant occurrence of attacks may result in trauma, stress and strain, tension, depression, anomy, severe mental disorders, and suicide. In present worse conditions, these psychotic problems may be experienced severely by individuals than before and may damage an individual's emotional equilibrium. Therefore, present study aimed at addressing the mental health consequences of terrorism exposures in general.

\section{Data and Methodology}

Crosses sectional study was conducted on youth because of constant threat to terrorism people have been experiencing various exposures to terrorism. For determining sample size, ${ }^{14}$ Taro Yamane's formula is used which provide simple formula to calculate your sample size. Where $\mathrm{n}$ is the sample size, $\mathrm{N}$ denotes population size, and e is level of precision that is .05 .

$$
n=\frac{N}{1+N(e)^{2}}
$$

\section{Sample size}

CIA Factbook (2015) informed that population of Pakistan lies between 15-24 years is $21.5 \%(422,668,01$ people)

\footnotetext{
${ }^{12}$ Qadri, Muhammad Ahmed and Qadri, Muhammad Abdullah, Terrorism: A serious threat to Transnational Borders, Equity, and Social Justice. A case study of Pakistan, Western Political Science Association, Annual Meeting Paper. (2011),

${ }^{13}$ Ahmed, A., Masood, K., Dean, S., Shakir, T., Kardar, A., Barlass, U., Imam, S., Mohmand, M., Ibrahim, H., Khan, I., Akram, U., Hasnain, F., "The constant threat of terrorism: stress levels and coping strategies amongst university students of Karachi." Journal of the Pakistan Medical Association, (2011) 61(4), 410-4. Accessed July 4, 2015,

${ }^{14}$ Yamane, Taro.. Statistics: An Introductory Analysis, $2^{\text {nd }}$ Ed., (New York: Harper and Row. 1967)
} 
Application of the Yamani's formula:

$$
\begin{gathered}
n=\frac{422,668,01}{1+422,668,01(0.05)^{2}} \\
n=\frac{422,668,01}{105667.005} \\
n=399.99
\end{gathered}
$$

Sample size of the study should be appropriate and commonly determines by keeping in view the research objectives. So, in this study, sample size was 399 respondents. Inclusion criteria was those students who are between the age of 15 to 24 and exclusion criteria was based on refusal of informed consent and data was collected from three cities namely Islamabad, Lahore and Sargodha city.

\section{Data collection}

After collection of information, sum of 413 questionnaires were collected and after scanning 14 questionnaires were dropped because those were incomplete in some respects.

\section{Research Tool}

As a research tool, an impact of event scale (IES-R) was modified slightly and used for the study. A modified structured questionnaire was used containing 19 questions. Among them, four questions were about types of exposures to terrorist attacks: a. b. c. d. for assessing impacts of constant threat of terrorism, Impact of event scale-Revised (IES-R) ${ }^{15}$ used. Firstly, questions of intrusion were asked: 1,2,3,4,5. Secondly, questions of hyper arousal were asked:6,7,8. Lastly, avoidance was evaluated in questions: 9,10,11,12,13,14,15. High levels of internal consistency have been reported (Intrusion: Cronbach's alpha $=.87-.94$, Avoidance: Cronbach's alpha $=.84-.87$, Hyper arousal: Cronbach's alpha $=.79-.91 .^{16}{ }^{17}$

\section{Analysis}

All data was put into Statistical Package of Social Sciences (V. 20). Then all statistical data was analyzed in STATA (V.12). For analysis, a multinomial model is applied because dependent variables have four categories.

\footnotetext{
${ }^{15}$ Christianson, Steven., \& Marren, Joan. "the Impact of Event Scale - Revised (IES-R)." Hartford institute, issue 19, (2013) Accessed from http://consultgerirn.org/uploads/File/trythis/try_this_19.pdf, Retrieved on July, 04,2015

${ }^{16}$ Creamer M, Bell R, Failla S. "Psychometric properties of the impact of event scale - revised." Behaviour Research and Therapy. (2003);41:1489-1496. [PubMed]

${ }^{17}$ Weiss DS, Marmar CR. "The impact of event scale - revised. In: Wilson JP, Keane TM, editors". Assessing psychological trauma and PTSD. New York: Guilford Press. (1997) pp. 399-411
} 


\section{Interpretations}

An individual has different experiences in his social life, these experiences may be good or bad as it depends on the event occurred in individual's life. In Pakistan, terrorist attacks have been risen up in past few years. In this way, inhabitants of the Pakistan have been experiencing such terrorist incidents for long time. Also, people are facing psychological problems and these psychological disorders depend on intensity of the hazard. As far as present study is concerned, researchers took respondents who have different exposures to terrorism and investigate the impact of terrorist attacks. People are categorized and then studied keeping in view the types of exposures to terrorist attacks.

In section of interpretation and discussions, researchers laddered down the empirical results in three categories named as intrusion, hyper arousal, and avoidance. These categories were determined in structured questionnaire while collecting data. In empirical analysis, media exposure is used as base category and following interpretations are circles around about this exposure.

Table No. 01

\begin{tabular}{|c|c|c|c|}
\hline \multicolumn{4}{|c|}{ Research model } \\
\hline & Intrusion & Hyper arousal & Avoidance \\
\hline McFadden's R2 & 0.291 & 0.133 & 0.129 \\
\hline $\begin{array}{c}\text { Cragg \& Uhler's } \\
\text { R2 }\end{array}$ & 0.397 & 0.262 & 0.257 \\
\hline AIC & 0.828 & 1.811 & 1.945 \\
\hline Count R2 & 0.891 & 0.604 & 0.616 \\
\hline BIC & -721.026 & -857.146 & -767.308 \\
\hline
\end{tabular}

Note: the score test is an overall value of the model is fit.

Table 1 shows at First in intrusion category, the value of McFadden's R2 is 0.291 that means the full model is far better fit. Secondly, the Cragg \& Uhler's R2 is 0.397 which shows it perfectly predicts the outcome because value is likelihood to 1 . Thirdly, the AIC is 0.828 that describes the model is better the fit. At fourth, count R2 is 0.891 that means predicted outcome is 1 . Lastly, the BIC value is -712.026 which tells that model is better the fit. Overall, the intrusion model is better the fit.

In hyper arousal, first value of McFadden's R2 is 0.133 that means the full model is far better fit. Secondly, the Cragg \& Uhler's R2 is 0.262 which shows it perfectly predicts the outcome because value is likelihood to 1 . Thirdly, the AIC is 1.811 that describes the model is better the fit. At fourth, count R2 is 0.604 that means predicted outcome is 1 . 
Lastly, the BIC value is -857.146 which tells that model is better the fit. Overall, the hyper arousal model is better the fit.

In avoidance, at First, the value of McFadden's R2 is 0.129 that means the full model is far better fit than the intercept model. Then, the Cragg \& Uhler's R2 is 0.257 which shows it perfectly predicts the outcome because value is likelihood to 1 . After that, the AIC is 1.945 that describes the model is better the fit. Lastly, count R2 is 0.616 that means predicted outcome is 1 . Lastly, the BIC value is -767.308 which tells that model is better the fit. Overall, the avoidance model is better the fit. Thus, it can be the said that research model is better the fit.

Table No. 02

\begin{tabular}{|c|c|c|c|c|c|}
\hline \multicolumn{6}{|c|}{ Multinomial model } \\
\hline \multicolumn{2}{|c|}{ Intrusion } & \multicolumn{2}{|c|}{ Hyper arousal } & \multicolumn{2}{|c|}{ Avoidance } \\
\hline & $\begin{array}{c}\text { Co- } \\
\text { efficient }\end{array}$ & & $\begin{array}{c}\text { Co- } \\
\text { efficient }\end{array}$ & & $\begin{array}{c}\text { Co- } \\
\text { efficient }\end{array}$ \\
\hline \multicolumn{6}{|c|}{ A person who in Informed by someone about an attack } \\
\hline \begin{tabular}{c}
\multicolumn{1}{c}{ Any } \\
reminder \\
brings....
\end{tabular} & -.3160377 & $\begin{array}{c}\text { Exposures } \\
\text { make me } \\
\text { angry.... }\end{array}$ & -.012463 & $\begin{array}{l}\text { I try that I } \\
\text { don't talk... }\end{array}$ & .0161707 \\
\hline $\begin{array}{c}\text { Feeling } \\
\text { trouble in } \\
\text { staying..... }\end{array}$ & -.3343301 & $\begin{array}{c}\text { I had problems } \\
\ldots . . .\end{array}$ & -.0902089 & $\begin{array}{l}\text { I try to } \\
\text { remove that } \\
\text { exposure.. }\end{array}$ & -.0350187 \\
\hline $\begin{array}{c}\text { I found } \\
\text { myself } \\
\text { feeling....... }\end{array}$ & .0897924 & $\begin{array}{l}\text { Reminders } \\
\text { caused to } \\
\text { sweating, } \\
\text { trouble...... }\end{array}$ & -.0145873 & $\begin{array}{c}\text { I try to stay } \\
\text { away from.... }\end{array}$ & -.0671493 \\
\hline $\begin{array}{c}\text { I had strong } \\
\text { feelings .... }\end{array}$ & -.320392 & & & $\begin{array}{l}\text { I aware that I } \\
\text { had strong } \\
\text { feeling..... }\end{array}$ & -.0042193 \\
\hline $\begin{array}{c}\text { Thinking of } \\
\text { it ...... }\end{array}$ & -.0093978 & & & $\begin{array}{c}\text { I think that it } \\
\text { hadn't } \\
\text { happen... }\end{array}$ & -.048133 \\
\hline & & & & $\begin{array}{l}\text { I try not to get } \\
\text { upset when.... }\end{array}$ & -.0545336 \\
\hline & & & & $\begin{array}{c}\text { I felt } \\
\text { watchful... }\end{array}$ & -.000585 \\
\hline \multicolumn{6}{|c|}{ A person who Knew someone injured in an attack } \\
\hline \begin{tabular}{c}
\multicolumn{1}{c}{ Any } \\
reminder \\
brings....
\end{tabular} & .2632674 & $\begin{array}{c}\text { Exposures } \\
\text { make me } \\
\text { angry..... }\end{array}$ & -.000658 & $\begin{array}{c}\text { I try that I } \\
\text { don't talk... }\end{array}$ & .0089199 \\
\hline $\begin{array}{c}\text { Feeling } \\
\text { trouble in } \\
\text { stayin..... }\end{array}$ & -.0217513 & $\begin{array}{c}\text { I had problems } \\
\ldots . . .\end{array}$ & .0178323 & $\begin{array}{l}\text { I try to } \\
\text { remove that } \\
\text { exposure.. }\end{array}$ & .001779 \\
\hline
\end{tabular}




\begin{tabular}{|c|c|c|c|c|c|}
\hline $\begin{array}{c}\text { I found } \\
\text { myself } \\
\text { feelin...... }\end{array}$ & .7829169 & $\begin{array}{l}\text { Reminders } \\
\text { caused to } \\
\text { sweating, } \\
\text { trouble...... }\end{array}$ & .0248309 & $\begin{array}{c}\text { I try to stay } \\
\text { away from.... }\end{array}$ & .035387 \\
\hline $\begin{array}{c}\text { I had strong } \\
\text { feelings .... }\end{array}$ & .5785588 & & & $\begin{array}{l}\text { I aware that I } \\
\text { had strong } \\
\text { feeling..... }\end{array}$ & -.0023899 \\
\hline $\begin{array}{c}\text { Thinking of } \\
\text { it ...... }\end{array}$ & -.044605 & & & $\begin{array}{c}\text { I think that it } \\
\text { hadn't } \\
\text { happen... }\end{array}$ & -.0108054 \\
\hline & & & & $\begin{array}{l}\text { I try not to get } \\
\text { upset when.... }\end{array}$ & -.0023771 \\
\hline & & & & $\begin{array}{c}\text { I felt } \\
\text { watchful... }\end{array}$ & .0011567 \\
\hline \multicolumn{6}{|c|}{ A person have Personal exposure } \\
\hline \begin{tabular}{c}
\multicolumn{1}{c}{ Any } \\
reminder \\
brings....
\end{tabular} & 1.312463 & $\begin{array}{c}\text { Exposures } \\
\text { make me } \\
\text { angry..... }\end{array}$ & .003851 & $\begin{array}{c}\text { I try that I } \\
\text { don't talk... }\end{array}$ & .0010838 \\
\hline $\begin{array}{c}\text { Feeling } \\
\text { trouble in } \\
\text { stayin..... }\end{array}$ & .3387884 & $\begin{array}{c}\text { I had problems } \\
\ldots \ldots .\end{array}$ & .0133584 & $\begin{array}{l}\text { I try to } \\
\text { remove that } \\
\text { exposure.. }\end{array}$ & .0049315 \\
\hline $\begin{array}{c}\text { I found } \\
\text { myself } \\
\text { feelin....... }\end{array}$ & 1.376773 & $\begin{array}{c}\text { Reminders } \\
\text { caused to } \\
\text { sweating, } \\
\text { trouble...... }\end{array}$ & .0047858 & $\begin{array}{c}\text { I try to stay } \\
\text { away from.... }\end{array}$ & -.0012956 \\
\hline $\begin{array}{c}\text { I had strong } \\
\text { feelings .... }\end{array}$ & -.3324359 & & & $\begin{array}{l}\text { I aware that I } \\
\text { had strong } \\
\text { feeling..... }\end{array}$ & .0015942 \\
\hline \multirow[t]{3}{*}{$\begin{array}{c}\text { Thinking of } \\
\text { it ...... }\end{array}$} & 1.874246 & & & $\begin{array}{c}\text { I think that it } \\
\text { hadn't } \\
\text { happen... }\end{array}$ & -.0006137 \\
\hline & & & & $\begin{array}{l}\text { I try not to get } \\
\text { upset when.... }\end{array}$ & .0028343 \\
\hline & & & & $\begin{array}{c}\text { I felt } \\
\text { watchful... } \\
\end{array}$ & .0011567 \\
\hline
\end{tabular}

a. The reference category is media exposure

\section{Intrusion}

\section{Any reminder brings back the feeling to exposures}

In comparison with media exposure as base category, a person who has personal exposure has $131 \%$ higher feelings of exposure, then a person who is informed by someone has $31 \%$ lesser feeling of exposures when he is reminded about, lastly a person who knew someone who injured or killed in an attack has $26 \%$ higher feelings of exposure after reminder. 


\section{Feeling trouble in staying or falling asleep}

It is unveiled, in comparison with media, that a person having personal exposure has $33 \%$ more trouble in falling asleep. Then a person who knew someone who is injured or killed has $2 \%$ lesser troubles regarding asleep. Next a person who is informed by someone has $31 \%$ lesser problems in falling or staying asleep.

\section{I found myself feeling as I was gone back at that Time}

Feelings as victim has gone back at that time, a person who is informed by someone has $8 \%$ higher alike feelings comparing to media exposure, a person having personal exposure has $138 \%$ higher alike feelings than a person having media exposure and a person knew someone who injured or killed in an attack has $78 \%$ higher alike feelings.

\section{I had strong feelings about exposures}

In comparison with media exposure, a person knew someone who killed or injured has 57\% more strong feelings, moreover person having personal exposure has 3\% less strong feelings and a person who in informed by someone has $3 \%$ less strong feelings.

\section{Thinking of it when I didn't mean to}

A person having personal exposure to an attack has $187 \%$ more feelings than a person having media exposure to an attack, a person who in informed by someone has $1 \%$ less likely feelings when he didn't mean it, however a person who knew someone injured or killed has $4 \%$ less feelings comparatively.

\section{Hyper Arousal}

In hyper arousal section of analysis, the base category is the same as media exposure.

\section{Exposures make me angry and irritable}

Weighing against media exposure, a person with personal exposure to an attack is $1 \%$ more likely to get angry and irritable because of the exposure, further, a person who knew someone injured or killed in an attack is $6 \%$ less likely angry and irritable, lastly a person who is informed by someone about an attack is $1 \%$ less likely angry and irritable. Similarly, a study conducted in Karachi (2011) provided evidence that irritability is most common symptoms among terrorist victims.

\section{I had problems in concentrating on things}

Analyzing media exposure to other exposures; a person who knew someone injured or killed in an attack and a person with personal exposure has both $1 \%$ more concentration problems. In contrast a person who is informed by someone has $9 \%$ less concentration problems. 
Reminders caused to sweating, trouble in breathing, vomiting, or speeding heart beat.

A person having personal exposure has faced $4 \%$ more physical reactions as compare to a person who has media exposure to terrorist attack when he is reminded of exposure, furthermore, a person knew someone who injured or killed in an attack has faced $2 \%$ less physical reactions and a person who is informed by someone has faced $1 \%$ less physical reactions.

\section{Avoidance}

\section{I try that I don't talk about that exposures}

A person who is informed by someone tried $1 \%$ more not to talk about the exposure comparing to media exposure, a person who knew someone injured or killed in an attack tried $1 \%$ more, and a person having personal exposure has tried $1 \%$ more not to talk about that exposure.

\section{I try to remove that exposure to my memory}

In comparison with media exposure, a person having personal exposure has tried $4 \%$ more try to remove that exposure to his memory, a person who is informed by someone $3 \%$ lesser try to remove the exposure from memory in comparison with media exposure, a person who knew someone injured or killed in an attack tried $1 \%$ more.

\section{I try to stay away from reminding that exposures}

A person who is informed by someone tried $6 \%$ lesser to stay away from reminding that exposure in comparison with media exposure, then a person having personal exposure has tried $1 \%$ lesser to stay away and a person knew someone who injured or killed in an attack tried $3 \%$ more to stay away.

\section{I aware that I had strong feeling about that incident and I couldn't deal with it}

Comparing to media exposure, A person who is informed by someone $4 \%$ less likely admitted that he had strong feelings and he could not deal with it, nevertheless a person having personal exposure $1 \%$ more likely admitted the fact that he could not deal with strong feelings and lastly a person knew someone who injured or killed $2 \%$ less likely admitted that he had strong feelings.

\section{I think that it hadn't happened to me or it was not real}

Put side by side to media exposure with other exposures, a person having personal exposure $6 \%$ less likely thought that he had not such exposure in his/her life, a person who is informed by someone is $4 \%$ less likely thought that it had not happened to $\mathrm{him} / \mathrm{her}$, a person knew someone who injured or killed is $1 \%$ less likely thought that exposure had not happened to me. 


\section{I try not to get upset when I am reminded about it}

Comparing to media exposure, a person who is informed by someone is 5\% less likely tried not to upset when he is reminded about exposure. a person having personal exposure $2 \%$ more tried not to upset when he is reminded about exposure and a person knew someone who injured or killed is $2 \%$ less likely tried not to upset when he is reminded about exposure.

\section{I felt watchful after it}

A person knew someone who injured or killed $2 \%$ more likely feel watchful comparing to media exposure. Then a person who is informed by someone is $5 \%$ less likely feel watchful. Next a person having personal exposure $1 \%$ more likely feels watchful.

\section{Discussions}

In the light of the aforementioned interpretations of the present study, it can be argued that a person who has personal exposure to terrorist attack is worst hit of terrorism as majority of findings shows high percentage in category of personal exposure. Possible reasons can be easily sort out because a person who physically present at the place of incident. He would obviously witness bloodshed and psychologically infused greater impacts rather than those who exposed to attack by indirect means like media, informed by someone, or knew someone injured or killed in an attack. Moreover, the least affected persons who are informed by someone about an attack. A person who knew someone has second relative high percentage in embracing effects of exposure to terrorist attack. Thus this study proved that psychological impacts on individuals varied as per exposure to terrorist attacks. In general, it can be argued that psychological health of the individual is affected with terrorism. Similar findings have been observed in the study conducted by Along with, a report addressed the problems of Chechnya and explored the psychological issues and found that majority of respondents said that conflict situation triggered their psychological make-up. ${ }^{18}$

\section{Conclusion}

It is concluded that persistence threat of terrorism is causing severe illness among youth. As they are the largest segment of Pakistani population, it is pivotal to address this menace in proactive means. So far, no initiative has been observed at any level to cope social risk associated with terrorism. Yet, this menace has been taken as security threat only but its long persistence threatens societal patterns of Pakistan. As present study rose serious concerns linking with mental health of youth, so it should be addressed on urgent basis. In dealing with these problems, alike studies would be instrumental in policy making.

\footnotetext{
${ }^{18}$ Human Right Watch . "Annual report 2003.” (2003) Retrieved from http://www.hrw.org/legacy/wr2k3/us.html, Retrieved on March 22, 2017
} 


\section{Suggestions}

Present study suggests that threat of terrorism should be addressed in all dimensions. Nevertheless, the sever impacts should be taken into consideration by authorities. A proper mechanism should be made where counseling should be provided to victims free of cost. Besides, while making counter terrorism policy, post-traumatic issues should also be considered along with other policy matters. However, this study is just beginning to address this threat, yet extensive researches can be conducted to address this menace broadly. As this study addressed specific region to benefit youth, it is being felt that menace of terrorism should be addressed at wider scale. Because youth is the future of any nation and this segment of society is at stake because of terrorism. For brighter future, we must have a healthy, physically and psychologically, youth which may strengthens the nation.

\section{Bibliography}

Ahmed, A., Masood, K., Dean, S., Shakir, T., Kardar, A., Barlass, U., Imam, S., Mohmand, M., Ibrahim, H., Khan, I., Akram, U., Hasnain, F., "The constant threat of terrorism: stress levels and coping strategies amongst university students of Karachi." Journal of the Pakistan Medical Association, (2011) 61(4), 410-4. Accessed July 4, 2015,

Ali, Saleem. Islam and education: conflict and conformity in Pakistan and beyond, (under review by Oxford University Press, 2007)

Badri ., Crutzen, Rik, Crutzen and Borne, H W Van den, "'Exposures to war-related traumatic events and post-traumatic stress disorder symptoms among displaced Darfuri female university students: an exploratory study."BMC Public Health. (2012); 12: 603. Accessed November 01, 2015, doi: 10.1186/1471-2458-12-603

Christianson, Steven., \& Marren, Joan. "the Impact of Event Scale - Revised (IES-R)." Hartford institute, issue 19, (2013) Accessed from http://consultgerirn.org/uploads/File/trythis/try_this_19.pdf, Retrieved on July, 04, 2015

Creamer M, Bell R, Failla S. "Psychometric properties of the impact of event scale revised." Behaviour Research and Therapy. (2003). [PubMed]

Crenshaw, M. "The logic of terrorism: terrorist behavior as a product of strategic choice. In Origins of Terrorism" (Cambridge: Cambridge University press, 1990) Dis 1992.

Greenberg,J.,Simon,L., Pyszczynski,T., Solomon,S. \& Chatel,D. Terror management and tolerance: does mortality salience always intensify negative reactions to others who threaten one's world view? Journal of Personality and Social Psychology, (1992).

Human Right Watch . "Annual report 2003.” (2003) Retrieved from http://www.hrw.org/legacy/wr2k3/us.html, Retrieved on March 22, 2017 
Naz, Arab., Daraz, Umar., Khan, Waseem., Khan Qaisar., \& Khan, Tariq. "Sociological analysis of Terrorism in Pakistan." Academic research journal, (2012),

Qadri, Muhammad Ahmed and Qadri, Muhammad Abdullah, Terrorism: A serious threat to Transnational Borders, Equity, and Social Justice. A case study of Pakistan, Western Political Science Association, Annual Meeting Paper. (2011),

Schlenger WE, Caddle JM, Ebert L, Jordan BK, Rourke KM, Wilson D. "Psychological reactions to terrorist attacks: findings from the National Study of American's Reactions to September 11.” JAMA (2002).

Shaley AY. "Posttraumatic stress disorder among injured survivors of a terrorist attack: predictive value of early intrusion and avoidance symptoms." Journal of Nervous and Mental diseases, (Aug, 1992)

Suarez, Eliana, "The association between post-traumatic stress-related symptoms, resilience, current stress and past exposure to violence: a cross sectional study of the survival of Quechua women in the aftermath of the Peruvian armed conflict." Conflict and Health, (2013), 7:21, Accessed on December 23, 2015, DOI: 10.1186/1752-1505-721

United Nations "Measures to eliminate international terrorism," of December 9, 1994, UN Doc. A/Res./60/49. 1994. Retrieved from http://www.un.org/documents/ga/res/49/a49r060.htm, retrieved on May, 02, 2016

Web desk, "80,000 Pakistanis killed in US 'War on Terror': report," The Tribune, March 29, 2015, accessed on June 06, 2015, http://tribune.com.pk/story/860790/80000pakistanis-killed-in-us-war-on-terror-report/

Weiss DS, Marmar CR. "The impact of event scale - revised. In: Wilson JP, Keane TM, editors". Assessing psychological trauma and PTSD. New York: Guilford Press. (1997)

World Health Organization. "Promoting Mental Health: Concepts, Emerging evidence, substance Abuse in collaboration with the Victorian Health Promotion Foundation and the University of Melbourne. World Health Organization. "Geneva 19. J.K.Trivedi. Indian Journal of Psychiatry, (2004)

Yamane, Taro. Statistics: An Introductory Analysis, $2^{\text {nd }}$ Ed., (New York: Harper and Row. 1967) 